ISSN 2616-7328 (Online), ISSN 2409-904X (Print)

Kitaêznavčì doslìdžennâ, 2019, No. 1, pp. 64-75

doi: https://doi.org/10.15407/chinesest2019.01.064

UDC 339.92

\title{
CURRENT STATUS OF ECONOMIC COOPERATION IN SOUTH-EAST ASIA
}

\author{
Y. Makohon \\ Doctor in Economics, Professor, \\ Honoured Worker of Science and Technology, \\ Vice-President of Economic Science Academy of Ukraine \\ Professor Emeritus, Harbin Commerce University (PRC) \\ Mariulpol State University, \\ 87500, Mariupol, 129a Budivelnykiv prospect \\ E-mail: makogon1947@gmail.com
}

Over the past decades, the importance of South-East Asia in the system of international economic relations has steadily increased, especially in the basin of the Pacific Ocean. In a way, this is due to the increasing relevance of such factors as favorable geographic and military-strategic location of the states of the region, their rich natural resources. But the increasing importance of the countries of South-East Asia in the modern world is due to their political and economic development. We must also consider that South-East Asia is an integral part of the Pacific region. Whose role and significance in the development of the world economy are recognized throughout the world.

The article is relevant, because it allows us to understand the way of forming the foreign policy and the economic growth of the countries of South-East Asia in the world based on some ideological preferences. The main goal of the article is to analyze the economic activity of the countries of South-East Asia, in particular Vietnam, and to determine the prospects of trade and economic cooperation between Ukraine and Vietnam. The region of South-East Asia is heterogeneous and does not form a group of countries characterized by certain social trends of socio-economic and political development.

The article provides a thorough analysis of the development of the East Asian model at the present stage, emphasizes the main advantages and disadvantages of cooperation with the countries of South-East Asia for Ukraine, as well as the criteria for the success of the development of the Asian region as a whole.

Keywords: South-East Asia, economic cooperation, ASEAN, East Asian model, trade and economic cooperation, state regulation.

\section{СУЧАСНИЙ СТАН ЕКОНОМІЧНОЇ СПІВПРАЦІ КРАЇН ПІВДЕННО-СХІДНОЇ АЗЇ̈}

\section{Ю. В. Макогон}

Південно-Східна Азія - динамічний регіон. 58 \% усіх працюючих у світі людей живуть в Азіатсько-Тихоокеанському регіоні. Економічне значення цієї частини світу зростає 3 кожним роком: населення стає більш заможними, а голос місцевих політиків на світовій арені звучить дедалі частіше. Разом із підйомом Східної Азії зменшується вплив Західної Свропи та Північної Америки.

C 2019 Y. Makohon; Published by the A. Yu. Krymskyi Institute of Oriental Studies, NAS of Ukraine and the Ukrainian Association of Sinologists on behalf of The Chinese Studies. This is an Open Access article distributed under the terms of the Creative Commons Attribution License (https://creativecommons.org/licenses/by-nc-nd/4.0/). 
Південно-Східна Азія займає важливе місце в сучасній світовій політиці та економіці. У регіоні проживає понад 630 млн осіб - більше, ніж в Європейському союзі або Північній Америці. Беззмінний лідер всього світу, що розвивається, Китай своїх позицій здавати не збирається - найменші зміни в економічних показниках країни потрапляють у заголовки провідних видань світу. Однак інвестори все частіше поглядають у бік 10 сусідніх із Китаєм країн, що входять в Асоціацію держав Південно-Східної Азії (АCЕАН). Заснована в 1967 році співдружність сьогодні включає в себе Бруней, Камбоджу, Індонезію, Лаос, Малайзію, М'янму, Філіппіни, Сінгапур, Таїланд і В'єтнам. Ці країни перебувають на різних стадіях розвитку, але мають однаково значний потенціал для економічного зростання в майбутньому. АСЕАН - центр глобального виробництва і торгівлі, а з недавнього часу ще й небувалого зростання споживчого попиту. Значення регіону буде тільки зростати, тому важливо розуміти всі його суперечності і складності. Асоціація стала дієвим інститутом підтримки політичної стабільності та безпеки в регіоні.

Швидке зростання населення, економічний розвиток, урбанізація, збільшення валової доданої вартості привертають увагу світових лідерів. У Західній Європі або в Північній Америці громадськість і політики звикли, що на світовій арені перш за все цікавляться тим, що відбувається на цих двох континентах. До недавнього часу побутувала така думка: те, що відбувається у Вашингтоні, важливо для всього світу, а те, що має місце в якомусь Бангкоку - це лише місцеві справи [Makohon \& Zharnikova 2017]. Проте за останні 15 років відбулися значні зміни, які показують, що центр світу поступово переходить до Східної Азії, а Західна Свропа і Північна Америка стають другорядними геополітичними гравцями.

Інформація про економічний підйом у Східній Азії з'явилася зовсім нещодавно. Фінансова консалтингова компанія Copgemini оголосила, що в АзіатськоТихоокеанському регіоні проживає найбільше мільйонерів, які володіють основними активами. Вперше цей регіон випередив таких лідерів, як Північна Америка та Західна Європа. За оцінками експертів, якщо багатство в Азіатсько-Тихоокеанському регіоні продовжуватиме зростати такими темпами, як у період з 2006 по 2015 рік, то після десяти років там буде накопичено більше світового багатства, ніж в Європі, Південній Америці, Африці та на Близькому Сході разом узятих [Yefymova 2019].

Новина про мільйонерів звичайно символічна, але регіон почав лідирувати і в набагато серйознішій сфері, яка стосується експорту. Бо не тільки в Китаї щорічно фіксується бурхливе економічне зростання, це саме відбувається в сусідніх країнах, таких як Малайзія, Індонезія і Філіппіни. Якщо 1990 року частка Азії в світовій економіці становила $23,2 \%$, то 2014 року вона досягла $38,8 \%$, а через десять років перевищить $45 \%$.

У Східній Азії швидко зростають доходи і споживання населення. У 2020 році витрати середнього класу збільшилися в два рази порівняно з 2009 роком. А до 2030 року вони виростуть у 6 разів. Такого стрибка в розвинених країнах неможливо було очікувати. Протягом майже десяти років бензину та інших видів палива азіати споживають більше, ніж американці, не кажучи вже про європейців. У ході прискореного промислового розвитку протягом останніх десятиріч країни Південно-Східної Азії досягли великих успіхів, хоча за своїми природним, науково-технічним потенціалом та багатьма показниками економічного розвитку вони відрізняються одна від одної. 
Аналіз промислового розвитку країн Південно-Східної Азії свідчить, що їхні економічні успіхи були досягнуті за рахунок комбінування чотирьох факторів: 1) експортно-промислової стратегії розвитку; 2) залучення іноземного капіталу; 3) державного регулювання; 4) створення життєздатних господарських суб'єктів - національних корпорацій [Interweb Pro 2015].

Сьогоднішнє сприятливе положення справ - результат довгого шляху, який пройдено регіоном, перш ніж він став інвестиційно привабливим і перспективним для вкладень. Про це відмінно написано в таких чудових книгах Джо Стадвелла (Joe Studwell), як “Азіатські хрещені батьки: гроші і влада в Гонконзі і Південно-Східній Азії” і “Як працює Азія: успіхи і провали самого динамічного регіону в світі”. У рамках же поточного дослідження, ми будемо спиратися на ті факти, які змогли з'ясувати самі у відкритих джерелах і в експертів по регіону.

1. Десять країн АСЕАН сукупно є сьомою за величиною економікою в світі, а за прогнозами експертів, до 2050 року АСЕАН вийде на четверте місце за обсягом економіки. За темпами розвитку регіон випереджає весь інший світ. Основу економічного розвитку становить зростання числа робочої сили та продуктивності. За кількістю працездатного населення країни АСЕАН посідають третє місце в світі після Китаю та Індії. Слід зазначити зростання ефективності їхніх економік і макроекономічну стабільність. В АСЕАН розташовані головні офіси 227 великих корпорацій. Це стимулює збільшення прямих іноземних інвестицій у регіон. За темпами розвитку регіон випереджає весь інший світ. Середній дохід на душу населення 1000 доларів на місяць (хоча середні дані сильно зміщені через багатих Малайзії та Сінгапуру), і він продовжує підвищуватися. Починаючи з 2000 року, реальні доходи його населення росли в середньому на $5 \%$ щорічно. Кількість бідних людей стрімко скорочується.

2. Південно-Східна Азія розташована на одному з найважливіших світових перехресть торгових шляхів. Сінгапур, Малайзія і Таїланд входять в число 50-ти країн, найбільш залучених у глобальну торгівлю. I регіон володіє всім необхідним, щоб продовжувати розвиватися за рахунок зростання торгових потоків. Через Південно-Східну Азію проходять шляхи з Свропи і Близького Сходу на Далекий Схід і в Австралію. Найбільше значення на авіатрасах мають аеропорти Сінгапура і Бангкока, а на морських шляхах - Малаккська протока, проекти будівництва каналу через перешийок, що відокремлює півострів Малакі від материка.

Незважаючи на історичні, культурні та мовні відмінності, держави АCEAН однаково зосереджені на економічному розвитку, і регіон буде привертати все більшу увагу інвесторів.

3. Демографічні особливості. Чисельність населення країн регіону близько 600 мільйонів осіб, при помірному щорічному прирості (на відміну від спаду в Європі або демографічного буму - без економічного базису - в Африці). Плюс молодість, досить високий рівень освіти, специфічна, але все ж явно виражена азіатська працьовитість і внесок уряду деяких країн у розвиток технологічної інфраструктури.

4. Економіка не залежить від експорту природних ресурсів настільки, як у багатьох країн, що розвиваються, наприклад, експортерів нафти. Рівень диверсифікації виробництва, крім Сінгапуру та Філіппін, досить високий. однаково розвинені видобувна галузь, промисловість і сфера послуг, тому світові коливання попиту на сировину не загрожують країнам критичною мірою. 
5. Країни АСЕАН активно залучені в глобальну торгівлю. Хоча економіка не залежить від експорту, але регіон все одно є одним з основних експортерів світу - його частка у світовому експорті дорівнює 7 \%. Кожна 3 країн АСЕАН спеціалізується на певних типах продукції. В'єтнам, наприклад, експортує текстиль і одяг, Сінгапур і Малайзія - електронну техніку, а Таїланд - автомобільні запчастини. Решта держав в основному поставляють на світові ринки цінну мінеральну та сільськогосподарську сировину - пальмову олію, какаобоби, вугілля, олово, нафту і газ, дорогоцінні метали.

6. Ринок АСЕАН не однорідний. Країни Південно-Східної Азії багато в чому не схожі одна на одну. Якщо Індонезія виробляє 40 \% продукції співдружності і є членом G20, то М'янма тільки недавно вийшла з багаторічної економічної ізоляції і працює над налагодженням ринкових механізмів. Ще один приклад відмінностей: ВВП на душу населення Сінгапуру 30-кратно перевищує аналогічний показник у Лаосі.

Відрізняються країни і культурно. 90 \% населення Філіппін - католики, тоді як переважна більшість індонезійців сповідують іслам, а 95 \% жителів Таїланду - буддисти. Само собою, існує безліч інших не менш значущих особливостей окремо взятих держав. Тому єдина стратегія просування в цьому регіоні інвесторам навряд чи підійде.

7. АСЕАН - новий центр споживчого попиту. Про позитивні перспективи свідчить і збільшення частки середнього класу, що підстьобує споживчий ринок, в тому числі онлайн-торгівлю - регіон цілком знаходиться на різних стадіях споживчого буму: від зародження, як на Філіппінах, до зрілого, високого рівня споживання в Сінгапурі. Мало не 67 млн сімей у країнах АСЕАН стали частиною споживчого класу, і до 2030 року це число може подвоїтися. Навряд чи можна вивести риси типового споживача в регіоні, проте певні тренди вже намітилися. Серед особливостей - попит на розваги, перевага сучасних форматів ритейлу і уважність до брендів (індонезійці, приміром, виключно віддані своїм улюбленим маркам).

Зростання споживання йде плеч-о-пліч з урбанізацією. $27 \%$ мешканців ACEАН живуть у містах, чисельність населення яких перевищує 200 тис. Протягом наступних 10 років ще 54 млн людей стануть городянами. Ще одна тенденція - розвиток онлайн-технологій. Проникнення мобільного зв'язку в регіоні становить $110 \%$, інтернетом користуються $35 \%$ жителів. При цьому не можна не відзначити, що сусідство досліджуваних країн із таким економічним велетнем, як Китай, призвело до серйозної залежності від його ключових показників. Країни Південно-Східної Азії надзвичайно чуйно реагують на кон'юнктуру “сусіда”, що цілком зрозуміло, гігантським об'мом як товарної пропозиції, так і попиту, що генерується китайською стороною, сильними (перш за все економічно і політично) китайськими діаспорами в країнах. Тому стан економіки Китаю прямо позначається на економіці країн ПівденноСхідної Азії, і цей фактор завжди слід брати до уваги. Прогноз темпів економічного зростання країн АСЕАН (Асоціація держав Південно-Східної Азії)5,1\% в 2015 році. Це перевищує середньосвітові показники. Причому через вже названі причини, стабільність регіону робить будь-які прогнози дуже високо ймовірними до виконання.

У місцевому інформаційному полі дуже активно популяризується тематика інтеграції країн, розповідається про взаємну співпрацю і успіхи. Однак у реальності цей процес має куди менші успіхи, оскільки регіон сформувався в 
нинішніх кордонах відносно недавно і більшість країн мають низку відкладених, але аж ніяк не забутих історичних претензій одна до одної. Чому інтеграція проводиться більше в сфері політичних ініціатив і рамкових угод, але не в реальному стані справ.

У сучасному світі існує безліч змішаних економік, де держава функціонує в положенні партнера і конкурента приватних фірм, з одного боку, з іншого несе відповідальність за нормальне функціонування ринку і підтримку правопорядку в економіці в цілому. Роль держави не обмежується виконанням функцій “нічного сторожа", а передбачає більш широке поле діяльності. Державне регулювання в ринковому господарстві - цілеспрямований вплив держави на мікро- і макроекономічні процеси розвитку економіки з метою підтримки їі стабільності або зміни в потрібному суспільству напрямку. Виділяють різні сторони - практичну і наукову.

Практичний досвід - це сукупність конкретних заходів для реалізації державного регулювання. Теоретичний аспект - систематичне наукове дослідження мотивів, дій, заходів, націлених на формування найбільш ефективного розвитку національної економіки. Виходячи із сутності, визначаються цілі державного регулювання. Аналізуючи стрімкі темпи зростання економіки країн Східної Азії, експерти Світового банку ретельно і досить всеосяжно досліджували систему і ефективність політики втручання урядів країн цього регіону в розвиток економіки своїх держав. Підсумок реферованого дослідницького досвіду в узагальненому вигляді сформулював резюме такої політикоекономічної конструкції: певні види і способи державного втручання - це кращий шлях стимулювання економічного підйому, ніж ортодоксальна (класична) теорія вільних ринкових відносин [Makohon \& Zharnikova 2017].

Перша з чотирьох рис “східно-азіатської моделі" - це те, що економіка цих країн починала свій шлях розвитку при диктаторських або жорстких політичних режимах. До інших трьох належать: експортна орієнтація промислового виробництва; розвиток приводить до початку демократизації; економічна свобода. Звідси народився вираз: “спочатку економіка, потім демократія”. Батько сінгапурських реформ Лі Куан, аналізуючи успіхи КНР, сказав: “Китайці спочатку зробили перебудову, і тільки потім прийшла гласність. Вони зробили це саме в цій послідовності, а не навпаки, у чому була найбільша помилка росіян" [Bkhaskaran 2018]. Політика державного управління економікою в східних країнах час від часу зазнає вельми істотних змін, коригування основних, базових напрямків розвитку економіки.

Індонезія, Малайзія і Таїланд в перші роки розвитку дотримувалися лінії на заміщення імпортних товарів власними промисловими виробами. Уряди згаданих країн найчастіше використовували комплексні політичні заходи для збільшення інвестицій у людський і фізичний капітал. Державні витрати на освіту в країнах Східної Азії не перевищували подібні асигнування в інших країнах. Однак азіати основну частину коштів спрямовували на розвиток початкової та середньої освіти з метою підготовки кваліфікованої, “білокомірцевої” робочої сили, а не на потреби університетів та інститутів. Але і вища освіта не обділена увагою. "Подивіться на кількість і якість інженерів, яких в даний час готують китайці",- вказує Лі Куан. В останні 25 років частка інвестицій приватного сектора у валовий внутрішній продукт країн Східної Азії була майже вдвічі вище, ніж в інших країнах, що розвиваються. Заслуговують на увагу деякі види втручання держави у формі податкових пільг, субсидій і дешевих 
позик, що необхідно ретельним чином вивчити і таким же чином технічно абсорбувати і використовувати в Киргизстані. Найбільшого успіху втручання урядів держав Східної Азії досягло в двох аспектах економічних реформ:

- у сприянні зростанню експорту;

- в цільових кредитах.

Більшість країн проводили політику енергійного стимулювання експорту шляхом надання субсидій, створення сприятливих умов для залучення іноземних кредитів та інвестицій. Наголос на зовнішні ринки сприяв піднесенню продуктивності промисловості, підйому приватного підприємництва [Interweb Pro 2015]. Певною мірою важливе значення надавалося маніпуляціям урядів із процентними ставками. Зокрема, держава втручалася у фінансово-кредитну систему і розподіл коштів, з тим, щоб знизити вартість капіталу для вітчизняних компаній і фірм, надати пільгові цільові кредити для пріоритетних галузей економіки. 3 метою зведення до мінімуму витрат державного втручання урядами країн Східної Азії були створені відповідні механізми і структури для контролю за преференційними галузями в рамках їхньої виробничої діяльності. На думку експертів Світового банку, Східна Азія дала світові деякі уроки. Найважливіший із них полягає в тому, що основи економіки:

- стабільність управління макроекономікою,

- інвестиції в людський фактор,

- відкриті ринки,

- надання цінами можливість відображати недоліки економіки - є найважливішими для успіху.

Аналізуючи вельми складну “азіатську” конструкцію державного управління ринковою економікою, не можна не згадати і про роль ідеології, традицій, певних морально-етичних цінностей і характеристик, притаманних народам країн Східної Азії, що має важливе значення в позитивному і негативному розвитку держави та суспільства. Найбільш складні ідеологічні та політичні “насадки”, як, наприклад, “конфуціанський капіталізм”, ідеї Сухарто, Махатхира (руху Негара), вимагають, звичайно, більш ретельного, більш глибокого вивчення і осмислення.

Економікам азіатських країн були притаманні багато структурних недоліків. Більшість фірм перебували в сімейному володінні, а відповідно до конфуціанської традиції сім’ї прагнули зберегти над ними контроль. Якщо вони і випускали акції у відкритий продаж, то зазвичай ігнорували права акціонерів, які перебували в меншості. Якщо їм не вдавалося фінансувати зростання фірми за рахунок доходів, вони покладалися на кредит, але не ризикували втратою контролю. У той же час урядовці використовували банківський кредит як інструмент фінансової політики; вони використовували його також із метою винагородити свої сім'ї і друзів. Існував порочний зв'язок між бізнесом і органами управління, i зазначене вище - лише один з його проявів. Поєднання таких факторів призвело до того, що співвідношення заборгованості до власного капіталу виявилося вкрай завищеним, а фінансовий сектор втратив прозорість і здорову основи. Ідея про те, що “банківський кредит” буде дисциплінувати акціонерів компанії, просто не спрацювала [Bkhaskaran 2018].

Структурні вади в банківській системі і формах володіння підприємствами; порочний зв'язок між бізнесом і політиками; недостатня прозорість і відсутність політичної волі - все це також мінуси “азіатської моделі”. Хоча перераховані недоліки були притаманні багатьом охопленим кризою країнам, але 
не всі вони характерні для кожної країни. Гонконг був вільний від більшості 3 цих недоліків. В Японії і на Тайвані існує політична свобода. Великі японські компанії не є сімейною власністю. У Сінгапурі існує міцна банківська система. Крім того, “азіатська модель" як така виявилася виключно успішною стратегією економічного розвитку і користувалася широкою популярністю в ділових колах. "Азіатська модель” забезпечила різке підвищення рівня життя, щорічний приріст сукупного доходу у відповідних країнах протягом тривалого періоду склав у середньому 5,5 \%, що набагато перевищує аналогічний показник практично у всіх ринкових економіках, що формуються. Азіатські лідери - Лі Кван Ю в Сінгапурі, Сухарто в Індонезії та Махатіра в Малайзії - 3 гордістю заявляли про свою впевненість у тому, що азіатські цінності вище західних, навіть коли криза вже вибухнула. Вони зайшли настільки далеко, що поставили під сумніви Декларацію ООН про права людини. Лі Кван Ю назвав західні демократії занепадницькими, Махатір засудив традиції колоніалізму, а Сухарто звеличував достоїнства непотизму. Асоціація країн Південно-Східної Азії (ACЕАН) прийняла в свої члени в червні 1997 р. М'янму, кинувши прямий виклик західним демократіям, які вважають репресивний режим М'янми неприйнятним у політичному і гуманітарному плані [Yefymova 2019].

Нова модель економіки В 'єтнаму. Нова модель в'єтнамської економіки, запропонована урядом після першого десятиліття 21-го століття, включає такі напрямки.

Реструктуризація промисловості та послуг. Це означає перехід від виробництва промислових виробів із низьким науково-технічним змістом і доданою вартістю до високого рівня доданої вартості, з акцентом на підтримку виробництва високотехнологічних продуктів, де В'єтнам має реальні можливості.

Реструктуризація підприємств. Для неї необхідно застосовувати новітні світові наукові і технологічні досягнення в сферах управління і виробництва, відповідно до цього реформувати і корпоративне управління. Реструктуризація підприємств є основою для створення нового обличчя в'єтнамської економіки.

Коригування маркетингової стратегії. Глобалізація і міжнародна інтеграція відкриває величезний ринок для підприємств, що дозволяє їм повною мірою використовувати переваги, що випливають з їхніх інвестиційних проектів. Але глобалізація також збільшує взаємозалежність економік, особливо з високим рівнем кооперації, як в’єтнамська.

Необхідно диверсифікувати продукцію та експортні ринки, обмежуючи залежність від кількох ринків, у той же час заохочувати розвиток внутрішнього ринку, особливо в сільській місцевості. На зовнішньому ринку зараз головне - не просто зростання експорту в одній країні або території, а проникнення в ланцюжок створення додаткової вартості.

Зменшення державних витрат у цілому і підвищення стимулів для залучення інвестицій із приватного сектора й іноземних фірм, розробка нових форм інвестування, зокрема, державно-приватного партнерства [MIT 2019].

Ключовими галузями, які разом повинні виступати “локомотивом” в'єтнамської економіки, вважаються електроенергетика, електроніка, харчова промисловість, суднобудування, сільськогосподарське машинобудування, виробництво автомобільних агрегатів і запчастин, видобуток і переробка нафти і газу, туризм.

В'єтнам - держава в Південно-Східній Азії, на східному узбережжі півострова Індокитай. Значна частина історії В'єтнаму пов'язана з колонізацією. У 
структурі економіки В'єтнаму домінують сфера послуг, промисловість (хімічна, легка, електроніка) і сільське господарство. За обсягом ВВП країна займає 57-ме місце в світі (з 187). Це досить високий показник, враховуючи розміри країни і іï скрутне становище в недавньому минулому.

У 2017 році В'єтнам експортував 220 млрд доларів, що дозволило йому посісти 21-ше місце за обсягом експорту серед країн світу. Протягом останніх років експорт В'єтнаму збільшився на 13,5 \%, з 116 млрд дол. у 2012 році до 220 млрд дол. у 2017 році.

В'єтнам експортує лісопродукцію для 120 країн. Велика її кількість імпортується в США, Японію і країни Євросоюзу. Головні деревообробні концерни розташовані в південній і центральній частині країни. Примітно, що тільки в одній провінції Бінь Зионг розташовані понад 200 компаній по деревообробці, 64 з яких створені з іноземними інвесторами. У В'єтнамі також випускається велика кількість меблів високої якості. Більша іiі частина йде на експорт. Целюлозне виробництво $є$ новим напрямком. Темпи зростання з року в рік тут вище, ніж в цілому по всій промисловості. Завдяки постійному удосконаленню технологій у сільськогосподарському секторі зростає виробництво продуктів харчування і їхній подальший експорт. Аграрна продукція, а також морепродукти, експортуються на 30 млрд доларів. Основна сільськогосподарська культура у В'єтнамі- це рис. Плантації займають величезні площі по всій країні, вони на рівнинах і навіть у гірській місцевості. Рис поставляється вже більш ніж в 70 країн світу, і з його експорту країна посідає 3 місце в світі. Експорт рису наблизився до 7 млн тонн. 350000 гектарів зайняті горіхами кешью. Експорт горіхів-кешью займає 1-ше місці в світі. В'єтнам тримає половину світового ринку чорного перцю, що дозволяє йому певною мірою впливати на ціни. Добре розвинене птахівництво, свинарство, бджільництво. Бідою птахівництва $є$ періодичні спалахи пташиного грипу, хоча в останні роки вони виникали значно рідше, ніж на початку 21 століття. Чайними плантаціями зайнято 125 тис. га в 33 провінціях. У чайній галузі зайняті півмільйона працівників. Активно розвивається рибальство та рибництво, видобуток і вирощування морепродуктів. Морепродукти у В'єтнамі дуже дешеві. Загальний експорт морепродуктів становить близько \$ 3,5 млрд на рік.

За показниками 2017-2018 pр. головними товарами експорту В'єтнаму є телерадіомовлення (30,7 млрд дол.), телефони (14,9 млрд дол.), інтегровані схеми (14,6 млрд дол.), текстильне взуття (9,5 млрд дол.) і шкіряне взуття (6,06 млрд дол).

У 2017 році В'єтнам імпортував 204 млрд дол. Протягом останніх років імпорт В'єтнаму збільшився за рік на 14,4 \%, з 102 млрд дол. у 2012 році до 204 млрд дол. у 2017 році. Його головним імпортом є інтегровані схеми (15,6 млрд дол.), телефони (10,2 млрд дол.), очищена нафта (7,23 млрд дол.), електричні частини (4,69 млрд дол.) і легкі прогумовані трикотажні вироби (4,51 млрд дол.).

Головними партнерами В'єтнаму з імпорту продукції є Сполучені Штати (46,2 млрд дол.), Китай (39,9 млрд дол.), Японія (18,1 млрд дол.), Південна Корея (16,1 млрд дол.) і Німеччина (10,9 млрд дол.). Найбільше В'єтнам експортує товар у Китай (70,6 млрд дол.), Південну Корею (47,7 млрд дол.), Японію (13,1 млрд дол.), Сінгапур (11,8 млрд дол.) і Гонконг (10,1 млрд дол.). Станом на 2017 рік В'єтнам мав позитивний торговельний баланс у розмірі 15,7 млрд дол. у чистому експорті [Vietnam News, 2019]. 
Країни Південно-Східної Азії за багатьма параметрами є дуже привабливими як для міжнародної експансії компаній, так і з точки зору інвестування в технологічні проекти. Немалу роль у цьому відіграє відчутна підтримка урядами азіатських країн. Останнім часом багато інвестиційних компаній відкривають або розглядають можливість відкриття офісів у Сінгапурі та КуалаЛумпурі, так, безумовно, простіше не пропустити цікаві проекти на ранніх стадіях, які стали з'являтися значно частіше.

В'єтнам є лідером регіону з розвитку легкої промисловості, великим світовим експортером кави, рису, горіхів кешью і меблів.

ВВП додає на 5,5 \% на рік. Серед країн ПСА тут найнижча середня зарплата (185 доларів). Втім, економія витрат на оплату праці вигідна експортерам, $\mathrm{i}$ ця ситуація використовується для прискорення зростання країни. Більш дешева, навіть ніж у Китаї, продукція дозволила В'єтнаму за рахунок більш низької собівартості виробництва стати номером один у легкій промисловості. Нарощуючи обсяги виробництва сільськогосподарської продукції, Україна активно розширює географію експорту. Україна нарощує експорт агропродукції в країни Азії - на 7,8 \% в порівнянні з аналогічним періодом минулого року.

Особливо питання пошуку та диверсифікації ринків збуту стає актуальними у зв'язку з погіршенням торговельних і політичних відносин з РФ. Одним iз найбільш перспективних ринків збуту української продукції є країни Південно-Східної Азії, в яких спостерігається зростання не тільки споживання сільгосппродукції, а й купівельної спроможності. Зі збільшенням виробництва зернових в Україні виникає питання про їхню реалізацію, розширення географії поставок. На мій погляд, країни Азії і є той ринок, де українське зерно знайде свого покупця. Найпривабливішим регіоном для експортерів $\epsilon$ ринок Південної та Південно-Східної Азії. Імпорт пшениці цим регіоном можна зіставити за величиною з імпортом африканськими країнами, він значно перевищує потреби країн СС та Близького Сходу. Важливість закріплення України на азіатському ринку важко переоцінити.

Торговельно-економічне співробітництво (TEC) між Україною і В'єтнамом грунтується на: Угоді між Урядом України і Урядом СРВ про торговельно-економічні відносини (1992 р.), Угоді між Урядом України та Урядом СРВ про створення Українсько-в’єтнамської Міжурядової комісії з торговельно-економічного та науково-технічного співробітництва (1993 р.), що була створена у 1994 році і до складу якої входять представники Мінекономрозвитку, Мінпромполітики, МЗС, Мінтрансу, Мінвуглепрому, МОН, ДКАУ, МОЗ, НАНУ.

Товарообіг між Україною та В'єтнамом протягом останніх двох років стабільно зростає. За результатами 2016 року В'єтнам став одним із найбільших торговельних партнерів України серед країн Азії та Тихоокеанського регіону. Згідно з інформацією Державної служби статистики України, за підсумками 2017 року товарообіг між Україною та В'єтнамом склав \$242,9 млн (зростання на рівні 17,6 \% порівняно з аналогічним періодом минулого року). Обсяг експорту склав \$ 48,6 млн і збільшився на 14,5\%.

Україна та В'єтнам мають чудові перспективи більш динамічного розвитку торговельно-економічних відносин. Згідно $з$ дослідженнями, проведеними у рамках написання Експортної стратегії України, В'єтнам входить на сьогодні до переліку країн, з якими Україна недоторговує. Це стосується зокрема продукції агросектору. Сьогоднішні домовленості нададуть додаткового імпульсу, аби надолужити втрачене і вже найближчим часом вийти на якісно новий рівень взаємовигідної співпраці [Ministry of Foreign Affairs of Ukraine 2018]. 
Україна зацікавлена у розвитку співпраці з В'єтнамом, особливо що стосується надання Україні дозволу на експорт продукції рослинного походження на ринок В'єтнаму. Україна також прагне поглибити співпрацю щодо виробництва продукції машинобудування, співпрацю в енергетичній сфері, а саме в проектах модернізації, реконструкції та будівництва нових електроенергетичних станцій на території В'єтнаму.

Висновки. Країни регіону за три останніх десятиліття зробили справжній стрибок від відсталості до високого рівня розвитку. Цьому сприяло:

- по-перше, країни АСЕАН мають виключно вигідне географічне положення. Вони розташовані на перетині найважливіших морських, повітряних шляхів, що ведуть з Тихого океану в Індійський;

- по-друге, країни Південно-Східної Азії мають багатющий мінеральносировинний потенціал. У цьому регіоні знаходяться запаси олова, вольфраму, хрому, деревини. С великі родовища нафти, газу, нікелевої, кобальтової, мідної руд, золота, дорогоцінних каменів, кам'яного вугілля, а також великі запаси гідроенергетичних і агрокліматичних ресурсів;

- по-третє, країни Південно-Східної Азії на сьогодні перебувають на першому місці в світі за припливом інвестицій, вони склали 39500000000 дол. У міру накопичення власних капіталів у низці країн Південно-Східної Азії утворилися інвестиційні потоки усередині регіону. Країни АСЕАН реалізують численні проекти у В'єтнамі, Лаосі, Камбоджі;

- по-четверте, трудові ресурси цих країн величезні, і для них характерні високі темпи відтворення, що дозволяє підприємцям дешево їх оцінювати;

- по-п'яте, за модель розвитку країни Південно-Східної Азії взяли японський капіталізм з його підвищеною увагою до останніх досягнень НTP і їхнього прискореного впровадження у практичну діяльність;

- по-шосте, розвиток експортоорієнтованого виробництва, що забезпечує цим країнам швидке вростання в світову економіку (електронно-обчислювальна техніка, побутова та промислова, текстиль, взуття, одяг, годинники, супертанкери, балкери, контейнеровози, автомобілі і т. ін.); виробляються засоби інформатики, біотехнології, волоконної оптики; в країнах Південно-Східної Азії відбувається поступовий перехід від трудомістких до капіталомістких виробництв;

- по-сьоме, зростає невиробнича сфера - транзитні міжнародні фінансові угоди, туризм (5 млн осіб на рік), тропічний курорт і т. ін.

Підводячи підсумок, можна сказати, що, незважаючи на історичні, культурні та мовні відмінності, держави однаково зосереджені на економічному розвитку. У недалекому майбутньому регіон може стати одним із лідерів світової економіки. Щоб це сталося, країнам необхідно вкладати кошти в розвиток інфраструктури та освіти. Крім цього, важливо зосередитися на подальшій інтеграції в рамках Південно-Східної Азії. Якщо всі перераховані завдання будуть вирішуватися успішно, то регіон буде привертати все більшу увагу інвесторів.

Для того щоб підвищити ефективність партнерства між Україною і В'єтнамом, ми пропонуємо:

1) Відкрити нові напрямки співпраці між Україною і В'єтнамом.

2) Залучити в'єтнамські корпорації до інвестиційних проектів на території України у сфері сільського господарства, будівництва, видобутку корисних копалин. 
3) Збільшити обсяг поставок продовольчих товарів із В'єтнаму в Україну, а з України - машин і устаткування.

4) Перейти до взаєморозрахунків у національних валютах.

5) Збільшити прийом в'єтнамських студентів до українських вузів і розвивати нові форми співпраці в сфері вищої освіти.

\section{ЛІТЕРАТУРА}

Ринок Південно-Східної Азії. Секрети економічного дива [Електронний pecypc]. Режим доступу: https://roem.ru/22-09-2015/207393/sea-macroregion/

Ману Бхаскаран. Південно-Східна Азія на підйомі. Збереження динаміки // Финансы и развитие. 2018. № 55.

Макогон Ю. В. Міжнародна торговельна політика України в умовах глобалізації та військово-політичного протистояння на сході країни // Економічний вісник Національного технічного університету України "Київський політехнічний інститут”. 2017. № 14. [Електронний ресурс]. Режим доступу: http://nbuv.gov.ua/UJRN/evntukpi_2017_14_17.

Офіційний сайт Посольства України в Соціалістичній Республіці В'стнам [Електронний ресурс]. Режим доступу: https://vietnam.mfa.gov.ua/ua/ ukraine-vn/trade

The observatory of economic complexity: Vietnam [Електронний ресурс]. Режим доступу: https://atlas.media.mit.edu/en/profile/country/vnm/

Бізнес у В'стнамі [Електронний ресурс]. Режим доступу: http://vietnamnews.ru/smallbiz

Єфимова Л. М. Південно-Східна Азія - динамічний регіон [Електронний pecypc]. Режим доступу: https://mgimo.ru/about/news/experts/yugo-vostochnayaaziya-dinamichnyy-region/

\section{REFERENCES}

Interweb Pro (2015), Rynok Pivdenno-Skhidnoi Azii. Sekrety ekonomichnoho dyva, available at: https://roem.ru/22-09-2015/207393/sea-macroregion/

Bkhaskaran M. (2018), "Pivdenno-Skhidna Aziia na pidiomi. Zberezhennia dynamiky", Fynansy y razvytye, № 55, pp. 2, 6-9. (In Ukrainian).

Makohon Y. V. \& Zharnikova A. I. (2017), "Mizhnarodna torhovelna polityka Ukrainy v umovakh hlobalizatsii ta viiskovo-politychnoho protystoiannia na skhodi krainy", Ekonomichnyi visnyk Natsionalnoho tekhnichnoho universytetu Ukrainy "Kyivskyi politekhnichnyi instytut”, № 14, pp. 100-105, available at: http://nbuv. gov.ua/UJRN/evntukpi_2017_14_17.

Ministry of Foreign Affairs of Ukraine (2018), Ofitsiinyi sait Posolstva Ukrainy $v$ Sotsialistychnii Respublitsi Vietnam, available at: https://vietnam.mfa.gov.ua/ua/ ukraine-vn/trade

MIT (2019), The observatory of economic complexity: Vietnam, available at: https://atlas.media.mit.edu/en/profile/country/vnm/

Vietnam News (2019), Biznes u Vietnami, available at: http://vietnamnews.ru/ smallbiz

Yefymova L. (2019), Pivdenno-Skhidna Aziia - dynamichnyi rehion, available at: https://mgimo.ru/about/news/experts/yugo-vostochnaya-aziya-dinamichnyy-region/ 


\section{СУЧАСНИЙ СТАН ЕКОНОМІЧНОЇ СПІВПРАЦІ КРАЇН ПІВДЕННО-СХІДНОЇ АЗІЇ}

\section{Ю. В. Макогон}

Протягом останніх десятиріч значення Південно-Східної Азії у системі міжнародних економічних відносин, насамперед у басейні Тихого океану, неухильно зростає. Певним чином це пов'язано з підвищенням актуальності таких факторів, як сприятливе географічне та військово-стратегічне розташування держав регіону, їхні багаті природні ресурси. Але ще більш посилене значення країн Південно-Східної Азії у сучасному світі зумовлене їхнім політичним та економічним розвитком. Треба також врахувати, що Південно-Східна Азія - це складова частина тихоокеанського регіону, підвищення ролі та значення якого у розвитку світового господарства визнане в усьому світі.

Стаття актуальна, оскільки дозволяє зрозуміти, як і на основі яких ідейних уподобань формувалася зовнішня політика і відбувалося економічне зростання країн Південно-Східної Азії у світі. Метою статті є аналіз економічної діяльності країн Південно-Східної Азії, зокрема В'єтнаму, та визначення перспектив торговельно-економічного співробітництва між Україною та В'єтнамом. Регіон Південно-Східної Азії неоднорідний і не складає групи країн, для яких характерні ті чи інші спільні тенденції соціально-економічного та політичного розвитку.

У статті проведено грунтовний аналіз східно-азіатської моделі економічного розвитку на сучасному етапі, підкреслено основні переваги та недоліки співробітництва 3 країнами Південно-Східної Азії для України, а також виокремлені критерії успіху розвитку азіатського регіону в цілому.

Ключові слова: Південно-Східна Азія, економічна співпраця, АСЕАН, східноазіатська модель, торговельно-економічне співробітництво, державне регулювання

\section{СОВРЕМЕННОЕ СОСТОЯНИЕ ЭКОНОМИЧЕСКОГО СОТРУДНИЧЕСТВА СТРАН ЮГО-ВОСТОЧНОЙ АЗИИ}

\section{Ю. В. Макогон}

В течение последних десятилетий значение Юго-Восточной Азии в системе международных экономических отношений, прежде всего, в бассейне Тихого океана, неуклонно растет. Определенным образом это связано с повышением актуальности таких факторов, как благоприятное географическое и военно-стратегическое расположение государств региона, их богатые природные ресурсы. Но еще более усиленное значение стран Юго-Восточной Азии в современном мире обусловлено их политическим и экономическим развитием. Надо также учесть, что Юго-Восточная Азия - это составная часть тихоокеанского региона, повышение роли и значения которого в развитии мирового хозяйства признано во всем мире.

Статья актуальна, поскольку позволяет понять, как и на основе каких идейных предпочтений формировалась внешняя политика и происходил экономический рост стран Юго-Восточной Азии в мире. Целью статьи является анализ экономической деятельности стран Юго-Восточной Азии, в частности Вьетнама, и определение перспектив торгово-экономического сотрудничества между Украиной и Вьетнамом. Регион Юго-Восточной Азии неоднородный и не составляет группы стран, для которых характерны те или иные общие тенденции социально-экономического и политического развития.

В статье проведен подробный анализ восточноазиатской модели экономического развития на современном этапе, подчеркнуто основные преимущества и недостатки сотрудничества со странами Юго-Восточной Азии для Украины, а также выделены критерии успеха развития азиатского региона в целом.

Ключевые слова: Юго-Восточная Азия, экономическое сотрудничество, АСЕАН, восточноазиатская модель, торгово-экономическое сотрудничество, государственное регулирование 